\title{
An investigation of the lead tin yellows type I and II and their use in Bohemian panel paintings from the Gothic period
}

\author{
Radka Šefců, Štěpánka Chlumská and Alena Hostašová*
}

\begin{abstract}
Background: Presented article summarizes the results of a broad-based survey on painting techniques used during the High and Late Gothic period in the Bohemian panel paintings located in the collections of the National Gallery in Prague. The work is focused on the specific use of yellow pigments - lead tin yellow type I and type II in the panel painting from the period around 1340-1550. In the scientific investigation supplementary microscopic and spectral analyses were made. A representative range of 57 micro-samples collected from the 36 panel paintings of the 21 Masters and their workshops was investigated by the methods of optical microscopy on polarizing microscope (OM). Molecular analysis of both types of yellow was performed using Raman micro-spectroscopy (RMS). The use of this technique was crucial for the nondestructive differentiation between each type of lead-tin yellow.

Results: Thanks to the Raman spectroscopy it was possible for the first time to map the usage of lead tin yellow type I and II in such a broad range. Combination of the analytical techniques brought the knowledge about the morphology of the grains and variability of the use of the lead tin yellows in the Bohemian panel paintings.
\end{abstract}

Conclusions: The contribution offers a systematic view on the outcomes and in a synoptic way consults the results of respective scientific methods. It clearly confirms both the temporally and locally specific use of both types of lead tin yellows. The presented facts are the results of interdisciplinary collaboration among the scientists and the art historian.

Keywords: Lead tin yellow type I, Lead tin yellow type II, Pigment, Bohemian panel paintings, Medieval period, Raman micro-spectroscopy

\section{Introduction}

In the presented article we would like to introduce the results of our survey focused on the painting techniques used during the High and Late Gothic period in the Bohemian panel paintings located in the collections of the National Gallery in Prague, in particular on the specific use of yellow pigments - lead tin yellow type I and lead-tin yellow type II. These types of pigments were identified on the panel paintings from the period around 1340-1550. A number of important Bohemian artworks was studied, among others the paintings of the Master of the Vyšší Brod Cycle (Höhenfurth, around 1340-1350), Magister Theodoricus and assistants (around 1360-1370) [1], the Master of the Třeboň Altarpiece (Wittingau,

\footnotetext{
* Correspondence: hostasova@ngprague.cz

National Gallery in Prague, Staroměstské nám. 12, 11000 Prague, Czech Republic
}

around 1370-1390) [2], the Master of the Rajhrad Altarpiece (around 1430), the Master of the St George Altarpiece (around 1470-1480), the oeuvre of the Master of the Litoměrice Altarpiece (around 1500-1520/1525) [3] and the Monogrammist IW (around 1520-1550) [4-9].

The oldest references that mention the usage and preparation of lead tin yellow pigments can be found in medieval manuscripts [10-12], but the situation is complicated by the ambiguous denominations of the yellows in various sources. According to Marrifield [13] three types of lead yellows existed, one of them called in Italian literature giallolino or giallorino with attribution fino or di Fiandra [14,15], in Western European literature it was called massicot [16,17]. The second type was denoted as giallo di vetro and was probably of Italian origin, the third one was Naples yellow, which contained also antimony [18]. The first two types are supposed to be lead-tin yellows and the literature sources illustrate that 
the preparation was connected with glass production $[19,20]$. From these literature sources we should mention the Bolognese Manuscript or more illustrative books of recipes of ancient glassmakers and the examples from the scientific literature that are preserved in transcriptions from the 16th and 17th century. These documents evidence the usage of lead and tin in preparation of yellow glass, enamels or ceramics and their connection with painting [21].

Lead tin yellow type I and type II can be distinguished by the chemical composition. Lead tin yellow type I has the chemical formula $\mathrm{Pb}_{2} \mathrm{SnO}_{4}$ with orthorhombic crystal structure and space group Pbam. Chemical formula of lead tin yellow type II was determined to be $\mathrm{PbSn}_{1-\mathrm{x}} \mathrm{Si}_{\mathrm{x}} \mathrm{O}_{3}$ and should have the structure of pyrochlore with space group Fd3m.

Some historical manuscripts contain the recipes with more detailed instructions for the preparation of the pigments, describing the amount of main substances [10], or the ratio of the components. Nevertheless, the precise directions for the preparation, which would include also the experimental conditions, are not known. For this reason some of the previous research works were focused on the preparation of the lead tin yellow type I and II and registered the conditions in which these pigments can be manufactured [22-24].

Lead tin yellow type I was prepared mixing the lead (II, IV) oxide $\mathrm{Pb}_{3} \mathrm{O}_{4}$ (lead (II) oxide $\mathrm{PbO}$ or both components are also possible) with tin oxide $\mathrm{SnO}_{2}$, and calcining them at elevated temperature.

$$
2 \mathrm{~Pb}_{3} \mathrm{O}_{4}+3 \mathrm{SnO}_{2} \rightarrow 3 \mathrm{~Pb}_{2} \mathrm{SnO}_{4}+\mathrm{O}_{2}
$$

The firing temperature was found to be higher than expected at the beginning by Jacobi, rather around $800-900^{\circ} \mathrm{C}$. At lower temperatures the presence of minium $\mathrm{Pb}_{3} \mathrm{O}_{4}$ was detected in the final product (the reaction was incomplete). At higher temperatures the decomposition of final product can occur and the presence of $\mathrm{PbO}$ and $\mathrm{SnO}_{2}$ can be expected in the mixture. However the presence of $\mathrm{PbO}$ as massicot can arise also from the improper ratio of primary substances even if the process is done at suitable temperatures [22,25].

Lead tin yellow type II was prepared by the calcination of lead tin yellow type I and silicon oxide at temperatures between $800-900^{\circ} \mathrm{C}$.

$$
\mathrm{Pb}_{2} \mathrm{SnO}_{4}+\mathrm{SiO}_{2} \rightarrow \mathrm{PbSn}_{1-x} \mathrm{Si}_{x} \mathrm{O}_{3}
$$

Also here the primary substances can be found in final mixture if the temperature is lower than necessary. At higher temperatures the pigment can decompose to the lead oxide $\mathrm{PbO}$, silicon oxide $\mathrm{SiO}_{2}$ and tin oxide $\mathrm{SnO}_{2}$.
The first identification of lead tin yellows by means of advanced instrumental techniques was carried out in 1940 in the Doener Institut in Munich by the emission spectroscopy [23]. Since then thanks to the development of the instrumental analytical techniques it was possible to confirm the presence of lead tin yellows in many other artworks. X-ray diffraction (XRD) or Raman spectroscopy can be used for this purpose [26-28]. Elemental analysis (such as scanning electron microscopy with energy dispersive analysis or $\mathrm{X}$-ray fluorescence) could be used as a complementary technique [29], but the differentiation of each type by the presence of silica could be misleading because of the frequent combination with earth pigments that contain quartz [30].

A summary of the historical usage of both types of yellow pigments in paintings was published by Kühn [31]. The work reports that the lead tin yellow type I was commonly used from the half of the 15th to the 18th century in the whole European region [19]. On the other hand an extended use of the lead tin yellow type II was documented in the period from the beginning of the 14th century to the first half of the 15th century especially in the Italian paintings where the connection to the glass production is pointed out [20]. Presence of this pigment in Italian paintings was relatively widely investigated and it was identified in paintings from the region of Tuscany (Florence, Pisa, Siena), Veneto (Venice) and Lazio (Viterbo) [32]. There are some rare examples in the literature where the Bohemian paintings are mentioned, usually in connection to the Bohemian glass production [20]. No broader investigation that would report on the presence of these pigments in Bohemian paintings has been carried out so far. From the beginning of the 15th century till the end of the 16th century there are some rather unique findings in the paintings of the Italian High Renaissance masters (Tintoretto) and the Dutch painter Hendrick ter Brugghen [33].

The use of both types of lead-tin yellows detected in a single painting is rare, for example in the painting by Veronese or El Greco. [34,35] In these cases the lead tin yellows type I and II were used always in the different parts of the painting, probably with the intention to obtain the different colour tone. On the other hand on the painting Gonfalone della Giustizia by Perugino (1496, Galleria Nazionale dell'Umbria, Perugia) and on the portrait of Lady Spenser by the British artist John Bettes (1590, private collection) the presence of both types of yellow in one layer was detected [36]. Thanks to the scientific examinations carried out in the National Gallery in Prague it was possible to extend the knowledge about the use of lead tin yellows and confirm the presence of lead tin yellow type I and II in many precious artworks of Bohemian provenance. 


\section{Experimental}

For the identification of lead tin yellows in the 36 artworks of Bohemian provenance 57 micro-samples from archive of the chemical-technological laboratory of the National Gallery in Prague were used. These samples were collected and archived in the period from $70^{\circ}$ of the 20th century till now, usually in context of the interventions of restoration and the connected scientific examinations. The samples are conserved in the form of cross-sections embedded in resins based on methyl methacrylate (Spofacryl, Clarocit), as microscopical preparations or also as individual pieces that remained after the microchemical analysis. Permanent microscopical preparations were prepared by fixing a small amount of pigment to the Canada balsam or acrylate binding media (Veropal KP 709) dissolved in organic solvents. Through the years standard analyses were performed in chemicaltechnological laboratory including especially analysis by means of optical microscopy, microchemical analyses or $\mathrm{X}$-ray fluorescence [37]. Standard analyses of the elemental composition were carried out on the cross-sections using a scanning electron microscope with energy-dispersive X-ray analysis (SEM/EDX) [38]. The element identification was done in points directly on the pigment particles or on small areas in the layers. Analyses using the SEM/EDX method were carried out on a JEOL JSM 6460 LA in the chemical-technological laboratory of the National Gallery in Prague or on a JEOL JXA 50A/EDAX electron micro-analyzer in the Geological Institute of the Academy of Sciences of the Czech Republic.

Raman spectroscopy was used during the investigations of all samples as the fundamental technique which allows to distinguish between the molecular structures of both types of yellow [39]. Standard pigments were analyzed before the real samples investigation by means of Raman spectroscopy and by optical microscopy. These pigments were acquired from Kremer Pigmente or Böke \& Fritz company and were indicated with the trademarks Lead Tin Yellow deep type I (Kremer No. 10110), Lead Tin Yellow I (Böke \& Fritz Art. No. 101-7) and Lead Tin Yellow type II (Kremer No. 10120). Other standard pigments were investigated during the study because their presence was expected to be found in the real samples (Table 1). These pigments were also provided by Kremer Pigmente or Böke \& Fritz company.

\section{Optical microscopy (OM)}

Observation of the cross sections was carried out on a polarizing microscope Eclipse 600 Nikon in reflected and transmitted light, in a dark field and after excitation by UV light using the UV filter of $330-380 \mathrm{~nm}$ and $450-490 \mathrm{~nm}$. Morphological characteristics of individual pigment grains in microscopical preparations were examined in transmitted polarized light in parallel (PPL) and crossed (XPL) nicols. The magnification used was usually 200-1000x. Micrographs of the preparations and also of the cross sections of real samples were made with a digital camera Nikon Coolpix 4500 and DS-Fi2.

\section{Raman micro-spectroscopy (RMS)}

Molecular analysis by means of Raman micro-spectroscopy (RMS) was performed on the individual pigment grains or on the cross-sections using the mapping mode for better observation of individual components present in colour

Table 1 Raman band wavenumbers of lead-tin yellow I and II and inorganic pigments that were usually observed in the painting layers

\begin{tabular}{|c|c|c|c|}
\hline Pigment & Chemical formula & Manufactured & Wavenumbers $\left(\mathrm{cm}^{-1}\right)$, laser $780 \mathrm{~nm}$ \\
\hline Azurite & $2 \mathrm{CuCO}_{3} \cdot \mathrm{Cu}(\mathrm{OH})_{2}$ & Böke \& Fritz & $\begin{array}{l}83 \mathrm{~s}, 112 \mathrm{w}, 153 \mathrm{~s}, 178 \mathrm{w}, 234 \mathrm{~m}, 237 \mathrm{w}, 263 \mathrm{vw}, 278 \mathrm{vw}, 328 \mathrm{w}, 398 \mathrm{vs}, 538 \mathrm{vw}, \\
762 \mathrm{w}, 837 \mathrm{w}, 934 \mathrm{w}, 1094 \mathrm{~s}, 1416 \mathrm{~m}, 1426 \mathrm{bm}, 1455 \mathrm{w}, 1574 \mathrm{~m}, 1650 \mathrm{vw}\end{array}$ \\
\hline Chalk (Calcit) & $\mathrm{CaCO}_{3}$ & Böke \& Fritz & 155w, 282 m, 712vw,1086vs, \\
\hline Lead tin yellow, type I. & $\mathrm{Pb}_{2} \mathrm{SnO}_{4}$ & Kremer 10100 & 80 m, 130vs, 196 m, 275sh, 292w, 379w, 457w, 525vw \\
\hline Lead tin yellow, type I. & $\mathrm{Pb}_{2} \mathrm{SnO}_{4}$ & Böke \& Fritz & 80 m, 130vs, 196 m, 272sh, 290w, 379w, 454w, 525vw \\
\hline $\begin{array}{l}\text { Lead tin yellow, type I. } \\
\text { (red particles) }\end{array}$ & $\mathrm{Pb}_{2} \mathrm{SnO}_{4}$ & Böke \& Fritz & 80 m, 130vs, 196 m, 272sh, 290w, 379w, 454w, 525vw, 547vw \\
\hline Lead tin yellow, type $\|$. & $\mathrm{Pb}(\mathrm{Sn}, \mathrm{Si}) \mathrm{O}_{3} / \mathrm{PbSn}_{1-x} \mathrm{SixO}_{3}$ & Kremer 10120 & 67 s, 138vs, 263 vw (sh), 325vw (sh), 450 sh, 635vw (sh) \\
\hline Lead white & $2 \mathrm{PbCO}_{3} \cdot \mathrm{Pb}(\mathrm{OH})_{2}$ & Kremer 46000 & 74 s, 104 s, 129 s, 142br, 414vw, 680vw, 966w, 1051s, 1364vw, 1476vw(br) \\
\hline Malachite & $2 \mathrm{CuCO}_{3} \cdot \mathrm{Cu}(\mathrm{OH})_{2}$ & Kremer 44400 & $\begin{array}{l}78 \text { m, } 151 \text { s, } 178 \text { s, } 218 \text { m, } 269 \text { m, } 353 \text { m, } 432 \text { s, 533w, 719w, 753w, 795ww, } \\
1093 w, 1367 w, 1491 s\end{array}$ \\
\hline Minium & $\mathrm{Pb}_{3} \mathrm{O}_{7}$ & Kremer 42500 & $\begin{array}{l}63 \mathrm{~m}, 86 \mathrm{vw}, 121 \mathrm{vs}, 143 \mathrm{~m}, 151 \mathrm{~m}, 220 \mathrm{w}, 289 \mathrm{sh}, 314 \mathrm{w}, 319 \mathrm{~m}, 417 \mathrm{vw}, \\
455 \mathrm{vw}, 549 \mathrm{~s}\end{array}$ \\
\hline Massicot & $\mathrm{PbO}$ & Kremer 43101 & $71 \mathrm{~m}, 87 \mathrm{~s}, 143 \mathrm{vs}, 288 \mathrm{~s}, 384 \mathrm{vw}$ \\
\hline Vermilion & $\mathrm{HgS}$ & Kremer 10610 & $101 w, 252 v s, 282 w(s h), 341 \mathrm{~m}$ \\
\hline Yellow ochre & $\mathrm{FeO}(\mathrm{OH})$ & Böke \& Fritz & 92 m, 144 m, 247w(sh), 263w, 301 m, 399vs, 480w(sh), 558w, 705vw \\
\hline
\end{tabular}

All standard pigments were manufactured by the companies Kremer or Böke \& Fritz; s - strong, $m$ - medium, w - weak, $v$ - very, sh - shoulder, br - broad. 
layers. Raman spectra were collected by the Raman microscope Nicolet DXR (Thermo Scientific, USA), equipped with a CCD camera for signal detection. Two diode lasers with wavelength of $532 \mathrm{~nm}$ and $780 \mathrm{~nm}$ and maximum power of $10 \mathrm{~mW}$ and $24 \mathrm{~mW}$, respectively, were used as the excitation source. The laser was focused on the sample through a $50 \times$ and $100 \times$ objective lens.

First of all the investigation of standard pigments was performed to identify the suitable measuring conditions for the pigments in order to keep the analytical technique nondestructive. Both types of laser were used for the analysis of standard pigments and the maximum power (MP) of each excitation source was determined. For the analysis of real samples the laser of $780 \mathrm{~nm}$ was preferred because of the lower energy of the excitation source and thus the higher resistance of the samples. The power of the laser depended on the composition of the pigment mixture and the sensitivity of individual components. Usually the power of $2-10 \mathrm{~mW}$ was used with acquisition time from 5 to 15 minutes. Mapping was performed on the selected samples using lower power of the laser and acquisition time from 1 to 3 minutes. The step of the acquisition was chosen to be $2-3 \mu \mathrm{m}$ investigating different areas of the samples. Raman spectra were processed in the program Omnic 9.

\section{Results and discussion}

The results that were obtained from the standard pigments pointed out some diversities and specifics in the identification of both yellows. From the real samples the use of the lead tin yellow type I and II in the artworks of Bohemian provenance was widely evidenced (Table 2).

\section{Standard pigments}

The particles of lead-tin yellow type I are made of very fine grains accumulated in the aggregates with angular, irregular, crumb-like morphology. The colour of the particles is very light yellow to white in reflected light. The particles are anisotropic, birefringent, under crossed polars white or light yellowish. On the other hand the particles of lead-tin yellow type II are bigger than the particles of type I and form medium-sized grains. The particles are translucent and have light yellow to orange yellow colour, very high relief and their surface has a rough, glassy appearance. The particles are isotropic under crossed polars and with lemon yellow internal reflections [40].

During the measurements of standard pigments (Kremer No. 10110, 10120, Böke \& Fritz Art.No.101-7) by means of Raman micro-spectroscopy a higher sensitivity of both yellows on the excitation laser of $532 \mathrm{~nm}$ was observed. The MP for laser of $532 \mathrm{~nm}$ was $1 \mathrm{~mW}$ for lead tin yellow type I and $4 \mathrm{~mW}$ for lead tin yellow type II. Laser of $780 \mathrm{~nm}$ was used for the investigation of the samples from the artworks because of the resistance of both pigments to the excitation source in full range of power. The disadvantage of this laser lies in the worse detection of some green pigments present in the pigment mixtures because of the very low Raman signal. These pigments (verdigris or malachite) were detected already during the previous investigations and were identified by means of optical microscopy, micro-chemical tests and SEM/EDS.

In Figures 1 and 2 Raman spectra collected from both types of standard pigments are presented. Composition of presented pigments lead tin yellow type I from Böke \& Fritz Art.No.101-7 as well as type II from Kremer No. 10120 shows certain non-uniformity from the chemical point of view. Spectrum of the type I shows the typical Raman bands (Table 1), with the main band at $130 \mathrm{~cm}^{-1}$, assigned to the lattice vibration of $\mathrm{Pb}-\mathrm{O}$ [23]. Variations in the spectral curve were observed in the region between 500-550 $\mathrm{cm}^{-1}$, where the double peak at $525 \mathrm{~cm}^{-1}$ and $547 \mathrm{~cm}^{-1}$ was observed in some cases (see Figure 1a, b). Variations in this region observed also by Clark, who was comparing the spectra of this pigment with the spectra collected by Vigouroux [41]. Both authors found in this region a single peak in their spectra and these peaks differ in maxima corresponding to the maxima of this doublet (Vigouroux - $540 \mathrm{~cm}^{-1}$, Clark - $524 \mathrm{~cm}^{-1}$ ). Raman band with the maximum around $549 \mathrm{~cm}^{-1}$ could be found also in the Raman spectrum of minium $\left(\mathrm{Pb}_{3} \mathrm{O}_{4}\right.$, spectrum in Figure 1c and the details below), which could be one of the components involved in the manufacture of the pigment, according to the literature sources [10]. The presence of minium in the composition of lead tin yellow type I can be caused by improper firing conditions, for example by the lower temperature during the calcination. Pigment lead tin yellow deep type I from Kremer No. 10110 demonstrated uniform composition within the measurements.

Lead tin yellow type II gave the typical bands in Raman spectra, with the main maximum corresponding to the vibration of $\mathrm{Pb}-\mathrm{O}$ at $138 \mathrm{~cm}^{-1}$ [23]. This type of yellow showed also non-uniform composition as showed in Figure $2 \mathrm{a}$ and $\mathrm{b}$. The Raman band at about $635 \mathrm{~cm}^{-1}$ is probably caused by the presence of tin oxide $\left(\mathrm{SnO}_{2}\right.$ cassiterite - in Figure 2c and the detail below), that could be also formed by improper firing conditions, for example by a higher calcination temperature.

\section{Paintings}

The wide investigation of the paintings of the Bohemian provenance clearly demonstrated the utilization of the lead tin yellow type II as an individual pigment earlier than was documented till now (see Table 2). This pigment was confirmed in the artworks assigned to the period from 1345(50) to 1420. The oldest examples of its use were detected in the panel paintings of the Master of the Vy̌šś 
Table 2 Description of the analysed panel paintings and samples

\begin{tabular}{|c|c|c|c|c|c|c|c|}
\hline Artist & Title of panel painting & $\begin{array}{l}\text { Gallery/ } \\
\text { Inv. No. }\end{array}$ & Dating & $\begin{array}{l}\text { Sample } \\
\text { no. }\end{array}$ & $\begin{array}{l}\text { Colour and description } \\
\text { of sampling area }\end{array}$ & $\begin{array}{l}\text { Type of lead-tin } \\
\text { yellow }\end{array}$ & In mixture of pigments \\
\hline $\begin{array}{l}\text { Master of the Vy̌̌ší } \\
\text { Brod Cycle }\end{array}$ & $\begin{array}{l}\text { Vyšší Brod Cycle - Adoration } \\
\text { of the Magi }\end{array}$ & CA, O 6788 & $1345-1350$ & $98-42-3$ & $\begin{array}{l}\text { green reverse side of } \\
\text { the cloak of Virgin Mary }\end{array}$ & $\|$ & $\begin{array}{l}\text { lead white, cooper green pigment, } \\
\text { probably earth pigments }\end{array}$ \\
\hline $\begin{array}{l}\text { Master of the Vyšší } \\
\text { Brod Cycle }\end{array}$ & $\begin{array}{l}\text { Vyšší Brod Cycle - Christ on } \\
\text { the Mount of Olives }\end{array}$ & CA, O 6789 & $1345-1350$ & $98-88-5$ & green cloak of St John & $\|$ & lead white, cooper green pigment \\
\hline $\begin{array}{l}\text { Master of the Vy̌̌ší } \\
\text { Brod Cycle }\end{array}$ & Vyšší Brod Cycle - Resurrection & CA, O 6792 & $1345-1350$ & 03-54-4 & $\begin{array}{l}\text { yellow reverse side } \\
\text { of the cloak }\end{array}$ & $\|$ & - \\
\hline \multirow[t]{2}{*}{$\begin{array}{l}\text { Master of the Vy̌šsi } \\
\text { Brod Cycle }\end{array}$} & \multirow[t]{2}{*}{$\begin{array}{l}\text { Vyšší Brod Cycle - Descent of } \\
\text { the Holy Ghost }\end{array}$} & \multirow[t]{2}{*}{ CA, O 6794} & \multirow[t]{2}{*}{$1345-1350$} & 07-48-3 & $\begin{array}{l}\text { green reverse side } \\
\text { of the red cloak }\end{array}$ & $\|$ & $\begin{array}{l}\text { yellow ochre, lead white, } \\
\text { copper green pigment }\end{array}$ \\
\hline & & & & $07-48-10$ & $\begin{array}{l}\text { yellow cloak on the } \\
\text { left side }\end{array}$ & $\|$ & - \\
\hline Magister Theodoricus & $\begin{array}{l}\text { Chapel of the Holy Cross at } \\
\text { castle Karlštejn - John Baptist }\end{array}$ & NPU, KA 3671 & 1360-1364 & KA 3671-1B & $\begin{array}{l}\text { green in cross in the } \\
\text { halo of the lamb }\end{array}$ & $\|$ & copper green pigment \\
\hline Magister Theodoricus & $\begin{array}{l}\text { Chapel of the Holy Cross at } \\
\text { castle Karlštejn - Angel }\end{array}$ & NPU, KA 3710 & 1360-1364 & KA 3710-1 & green wing of angel & $\|$ & $\begin{array}{l}\text { copper green pigment, } \\
\text { yellow ochre }\end{array}$ \\
\hline Magister Theodoricus & $\begin{array}{l}\text { Chapel of the Holy Cross at } \\
\text { castle Karlštejn - Lamb of god }\end{array}$ & NPU, KA 3711 & 1360-1364 & KA 3711-1 & $\begin{array}{l}\text { green in the halo } \\
\text { of the lamb }\end{array}$ & $\|$ & $\begin{array}{l}\text { copper green pigment, } \\
\text { yellow ochre, traces of azurite }\end{array}$ \\
\hline \multirow[t]{5}{*}{ Anonym (Prague) } & \multirow[t]{5}{*}{$\begin{array}{l}\text { Votive Panel of John Očko } \\
\text { from Vlašim }\end{array}$} & \multirow[t]{5}{*}{$\mathrm{NG}, \mathrm{O} 84$} & \multirow[t]{5}{*}{ before 1371} & $91-6-7$ & $\begin{array}{l}\text { green reverse side of } \\
\text { the cloak of Virgin } \\
\text { Mary (highlight) }\end{array}$ & $\|$ & traces of vermilion, black \\
\hline & & & & $91-6-8$ & $\begin{array}{l}\text { green reverse side } \\
\text { of the cloak of Virgin } \\
\text { Mary (shadow) }\end{array}$ & $\|$ & $\begin{array}{l}\text { copper green pigment, } \\
\text { traces of black, vermilion }\end{array}$ \\
\hline & & & & $91-6-14$ & $\begin{array}{l}\text { yellow robe of the } \\
\text { St Ludmila }\end{array}$ & $\|$ & $\begin{array}{l}\text { yellow ochre, vermilion, } \\
\text { traces of black }\end{array}$ \\
\hline & & & & $91-6-16$ & $\begin{array}{l}\text { yellow robe of the } \\
\text { St Ludmila (shadow) }\end{array}$ & $\|$ & yellow ochre, traces of black \\
\hline & & & & $91-6-20$ & $\begin{array}{l}\text { yellow handle of the } \\
\text { sword }\end{array}$ & $\|$ & lead white \\
\hline \multirow[t]{3}{*}{$\begin{array}{l}\text { Master of the Třeboň } \\
\text { Altarpiece and his workshop }\end{array}$} & \multirow[t]{3}{*}{$\begin{array}{l}\text { Crucifixion from the church } \\
\text { of St Barbora }\end{array}$} & \multirow[t]{3}{*}{ NG, O 577} & \multirow[t]{3}{*}{ late 1370 s } & 08-43-3 & decorated robe of soldier & $\|$ & $\begin{array}{l}\text { cooper green pigment } \\
\text { (probably verdigris) (degraded) }\end{array}$ \\
\hline & & & & $\mathrm{H}-6$ & soldier's robe & $\|$ & - \\
\hline & & & & $\mathrm{H}-12$ & $\begin{array}{l}\text { reverse side, imitation } \\
\text { of the marble }\end{array}$ & $\|$ & - \\
\hline $\begin{array}{l}\text { Master of the Třeboň } \\
\text { Altarpiece }\end{array}$ & $\begin{array}{l}\text { Deposition/SS Giles, Augustine, } \\
\text { Jerome }\end{array}$ & NG, O 1266 & after 1380 & $10-28-2 B$ & $\begin{array}{l}\text { decorated yellow robe } \\
\text { of St Jerome }\end{array}$ & $\|$ & lead white \\
\hline \multirow[t]{2}{*}{ Anonym (Prague,?) } & \multirow[t]{2}{*}{$\begin{array}{l}\text { Madonna with SS Bartholomew } \\
\text { and Margaret }\end{array}$} & \multirow[t]{2}{*}{ NPU } & \multirow[t]{2}{*}{ ca. 1390} & $11-32-2$ & $\begin{array}{l}\text { green cloak of } \\
\text { St Margaret (highlight) }\end{array}$ & $\|$ & $\begin{array}{l}\text { yellow ochre, lead white, cooper } \\
\text { pigment (probably verdigris) }\end{array}$ \\
\hline & & & & $11-32-3$ & $\begin{array}{l}\text { green cloak of St Margaret } \\
\text { (shadow) }\end{array}$ & $\|$ & $\begin{array}{l}\text { yellow ochre, lead white, cooper } \\
\text { pigment (probably verdigris) }\end{array}$ \\
\hline
\end{tabular}


Table 2 Description of the analysed panel paintings and samples (Continued)

\begin{tabular}{|c|c|c|c|c|c|c|c|}
\hline \multirow[t]{3}{*}{$\begin{array}{l}\text { Master of the Třebon Altarpiece } \\
\text { and his workshop }\end{array}$} & Our Lady Ara Coeli & NG, O 1457 & $1385-1390$ & $08-35-1$ & $\begin{array}{l}\text { yellow cloak of } \\
\text { St Jerome }\end{array}$ & $\|$ & lead white \\
\hline & & & & $08-35-2$ & $\begin{array}{l}\text { green cloak of } \\
\text { St Margaret }\end{array}$ & | and || & verdigris, lead white \\
\hline & & & & 08-35-8 & $\begin{array}{l}\text { green robe of } \\
\text { Prophet Ezekiel }\end{array}$ & $\|$ & verdigris, lead white \\
\hline Anonym (Prague) & $\begin{array}{l}\text { Votive Panel, called from } \\
\text { Dubeček }\end{array}$ & NG, O 693 & $\begin{array}{l}\text { before } \\
\text { ca. } 1390\end{array}$ & $08-41-12$ & $\begin{array}{l}\text { green drapery of } \\
\text { St Vitus }\end{array}$ & I & verdigris, lead white \\
\hline Anonym(Prague) & $\begin{array}{l}\text { Triptych with Death of the } \\
\text { Virgin called the Roudnice } \\
\text { Altarpiece - inside of right } \\
\text { wing, Man of Sorrows and } \\
\text { eight kneeling devotes }\end{array}$ & NG, O 1466 & ca. $1410-1420$ & $10-56-6$ & $\begin{array}{l}\text { yellow collar of } \\
\text { the bishop }\end{array}$ & | and || & lead white, vermilion \\
\hline Master of the Rajhrad Altarpiece & Last supper & MGB, A 624 & ca. $1430-1440$ & $11-16-2$ & green cloak & I & lead white, verdigris \\
\hline $\begin{array}{l}\text { Master of the Saint George } \\
\text { Altarpiece }\end{array}$ & $\begin{array}{l}\text { St Vitus/ Eagle - Symbol of } \\
\text { the St John the Evangelista }\end{array}$ & NG, O 7035 & ca. 1470 & $09-27-2$ & brown cloak of St Vitus & । & lead white, verdigris \\
\hline Hans Maler Jr. (?) & $\begin{array}{l}\text { Retable, called from Kadaň - } \\
\text { Annunciation/Nativity }\end{array}$ & NG, O 7036 & ca. 1480 & $12-57-7$ & yellow robe of angel & । & lead white \\
\hline \multirow[t]{3}{*}{$\begin{array}{l}\text { Master of the Vejprnice (Budňany) } \\
\text { Altarpiece and workshops }\end{array}$} & $\begin{array}{l}\text { Annunciation to the Virgin } \\
\text { Mary, Circumcision/Crucifixion, } \\
\text { Crowning of Christ with } \\
\text { Crown of Thorns }\end{array}$ & NG, O 1334 & after 1490 & $09-38-2$ & Veronica's veil & । & lead white, verdigris \\
\hline & & & & $09-38-3 A$ & green cloak of angel & । & lead white, verdigris \\
\hline & & & & $09-38-5 A$ & white robe of angel & । & lead white \\
\hline \multirow[t]{2}{*}{$\begin{array}{l}\text { Master of the Vejprnice (Budňany) } \\
\text { Altarpiece and workshops }\end{array}$} & $\begin{array}{l}\text { Nativity, Adoration of the } \\
\text { Magi/Resurrection, Assumption }\end{array}$ & NG, O 1335 & after 1490 & $09-39-1 A$ & $\begin{array}{l}\text { guard's turban and } \\
\text { background }\end{array}$ & । & lead white, yellow ochre \\
\hline & & & & $09-39-5 A$ & king's robe & । & verdigris, lead white \\
\hline $\begin{array}{l}\text { Master of the Rakovnik } \\
\text { Altarpiece }\end{array}$ & The scourging of Christ & TGM Rakovnik & 1496 & $06-77-1$ & yellow, soldier's leg & । & $\begin{array}{l}\text { lead white, quartz, red } \\
\text { pigment }\end{array}$ \\
\hline $\begin{array}{l}\text { Master of the Rokycany } \\
\text { Altarpiece }\end{array}$ & Adoration of the Magi & NM, VO 11260 & before 1500 & $06-51-8$ & grey drapery & I & verdigris \\
\hline \multirow{2}{*}{$\begin{array}{l}\text { Master of the Rokycany } \\
\text { Altarpiece }\end{array}$} & Bearing of the Cross & NM, VO 11260 & before 1500 & $06-57-3$ & yellow turban & I & lead white \\
\hline & & & & $06-57-7$ & green ground & । & $\begin{array}{l}\text { verdigris, lead white, traces of } \\
\text { yellow ochre }\end{array}$ \\
\hline \multirow[t]{2}{*}{$\begin{array}{l}\text { Master of the Litoměrice } \\
\text { Altarpiece }\end{array}$} & St Andrew (fragment) & MGB & around 1500 & $06-52-4$ & green cloak & । & $\begin{array}{l}\text { azurite, cooper green pigment } \\
\text { (verdigris), lead white }\end{array}$ \\
\hline & & & & $06-52-5$ & green background & । & azurite, lead white, red ochre \\
\hline Master of the Litoměřice & Litoměřice Altarpiece - Nativity & SGVU & $1500-1505$ & $06-84-3$ & grey background & । & lead white, ochres, vermilion \\
\hline
\end{tabular}


Table 2 Description of the analysed panel paintings and samples (Continued)

\begin{tabular}{|c|c|c|c|c|c|c|c|}
\hline \multirow[t]{2}{*}{$\begin{array}{l}\text { Master of the Litoměrice } \\
\text { Altarpiece }\end{array}$} & $\begin{array}{l}\text { Litomerrice Altarpiece - } \\
\text { Bearing of the Cross }\end{array}$ & SGVU & $1500-1505$ & $06-89-1$ & yellow armour of soldier & । & lead white, red lake, fluorite \\
\hline & & & & $06-89-7$ & green drapery & 1 & verdigris, lead white \\
\hline $\begin{array}{l}\text { Master of the Litoměřice } \\
\text { Altarpiece }\end{array}$ & Strahov Altarpiece - Annunciation & KKPS & around 1505 & $12-32-1$ & yellow ray of light & | and || & lead white \\
\hline $\begin{array}{l}\text { Master of the Litoměřice } \\
\text { Altarpiece and workshop }\end{array}$ & $\begin{array}{l}\text { St Anne with the Virgin Mary } \\
\text { and the Christ Child }\end{array}$ & NG, O 4102 & around 1510 & $08-51-6$ & yellow belt of St Anna & 1 & lead white, yellow ochre \\
\hline $\begin{array}{l}\text { Master of the Litoměřice } \\
\text { Altarpiece and workshop }\end{array}$ & $\begin{array}{l}\text { Altarpiece panels, called from } \\
\text { Theyn (Týn) - St Barbara }\end{array}$ & MHMP & after 1510 & $06-60-3$ & green robe & 1 & azurite, lead white \\
\hline \multirow[t]{2}{*}{$\begin{array}{l}\text { Master of the Litoměřice } \\
\text { Altarpiece and workshop }\end{array}$} & $\begin{array}{l}\text { Altarpiece panels, called from } \\
\text { Theyn (Týn) - St Peter and } \\
\text { St Andrew }\end{array}$ & MHMP & after 1510 & $99-33-2$ & $\begin{array}{l}\text { green cloak of } \\
\text { St Andrew (highlight) }\end{array}$ & । & verdigris, lead white \\
\hline & & & & $99-33-3$ & $\begin{array}{l}\text { green cloak of } \\
\text { St Andrew (shadow) }\end{array}$ & । & verdigris, lead white \\
\hline \multirow[t]{3}{*}{$\begin{array}{l}\text { Master of the Litoměrice } \\
\text { Altarpiece }\end{array}$} & $\begin{array}{l}\text { St Catherine Altarpiece - } \\
\text { St Catherine before the } \\
\text { Emperor Maxentius }\end{array}$ & NG, O 17425 & around 1515 & $98-79-4$ & yellow stocking & । & $\begin{array}{l}\text { lead white, yellow ochre, } \\
\text { vermilion }\end{array}$ \\
\hline & & & & $98-79-5$ & $\begin{array}{l}\text { green cloak of the } \\
\text { Emperor }\end{array}$ & | and || & verdigris, lead white \\
\hline & & & & $98-79-12$ & $\begin{array}{l}\text { yellow robe of } \\
\text { St Catherine }\end{array}$ & । & lead white, yellow ochre \\
\hline \multirow[t]{2}{*}{$\begin{array}{l}\text { Master of the Litoměřice } \\
\text { Altarpiece and workshop }\end{array}$} & $\begin{array}{l}\text { St Catherine Altarpiece - } \\
\text { Entombment of St Catherine }\end{array}$ & NG, O 17426 & around 1515 & $98-78-5 A$ & green robe of angel & । & $\begin{array}{l}\text { verdigris, lead white, } \\
\text { yellow ochre }\end{array}$ \\
\hline & & & & $98-78-10$ & green wing of angel & । & lead white, azurite, vermilion \\
\hline $\begin{array}{l}\text { Master of the Litoměřice } \\
\text { Altarpiece and workshop }\end{array}$ & Martyrdom of St Catherine & NG, O 12306 & around 1515 & $99-13-3$ & $\begin{array}{l}\text { green cloak of the } \\
\text { Emperor }\end{array}$ & 1 & verdigris, lead white \\
\hline $\begin{array}{l}\text { Master of the Litoměřice } \\
\text { Altarpiece and workshop }\end{array}$ & St Catherine Reading & NG, O 12306 & around 1515 & $99-17-8$ & $\begin{array}{l}\text { green cloak of the } \\
\text { Emperor }\end{array}$ & । & verdigris, lead white \\
\hline Monogrammist IW & St Wenceslas/SS Catherina, Barbara & NG, O 1258 & around 1520 & $09-49-3$ & $\begin{array}{l}\text { yellow reverse side of } \\
\text { the cloak of St Barbara }\end{array}$ & । & lead white \\
\hline \multirow[t]{3}{*}{ Monogrammist IW } & $\begin{array}{l}\text { Altarpiece with the Execution of } \\
\text { St Barbara, called the St Barbara } \\
\text { Altarpiece from Osek - } \\
\text { St Sebastian/St Paul }\end{array}$ & NG, DO 5428 & after 1546 & 02-18-51 & $\begin{array}{l}\text { flesh (highlight), } \\
\text { St Sebastian }\end{array}$ & । & $\begin{array}{l}\text { lead white, black pigment, } \\
\text { chalk, red pigment }\end{array}$ \\
\hline & & & & $02-18-52$ & $\begin{array}{l}\text { flesh (shadow), } \\
\text { St Sebastian }\end{array}$ & । & $\begin{array}{l}\text { lead white, black pigment, } \\
\text { chalk, red pigment }\end{array}$ \\
\hline & & & & 02-18-Pa1 & flesh, St Paul & 1 & lead white, red lake \\
\hline
\end{tabular}

CA - Cistercian Abbey at Vyšší Brod, NG - National Gallery in Prague, NPÚ - National Heritage Institute, NM - National Museum in Prague, TGM Rakovník - Museum of Tomáš Garrigue Masaryk, MGB - Moravian Gallery in Brno, SGVU - SGVU Art Gallery in Litoměřice, MHMP - Museum of Prague, KKPS - Royal Canonry of Premonstratensians at Strahov. 


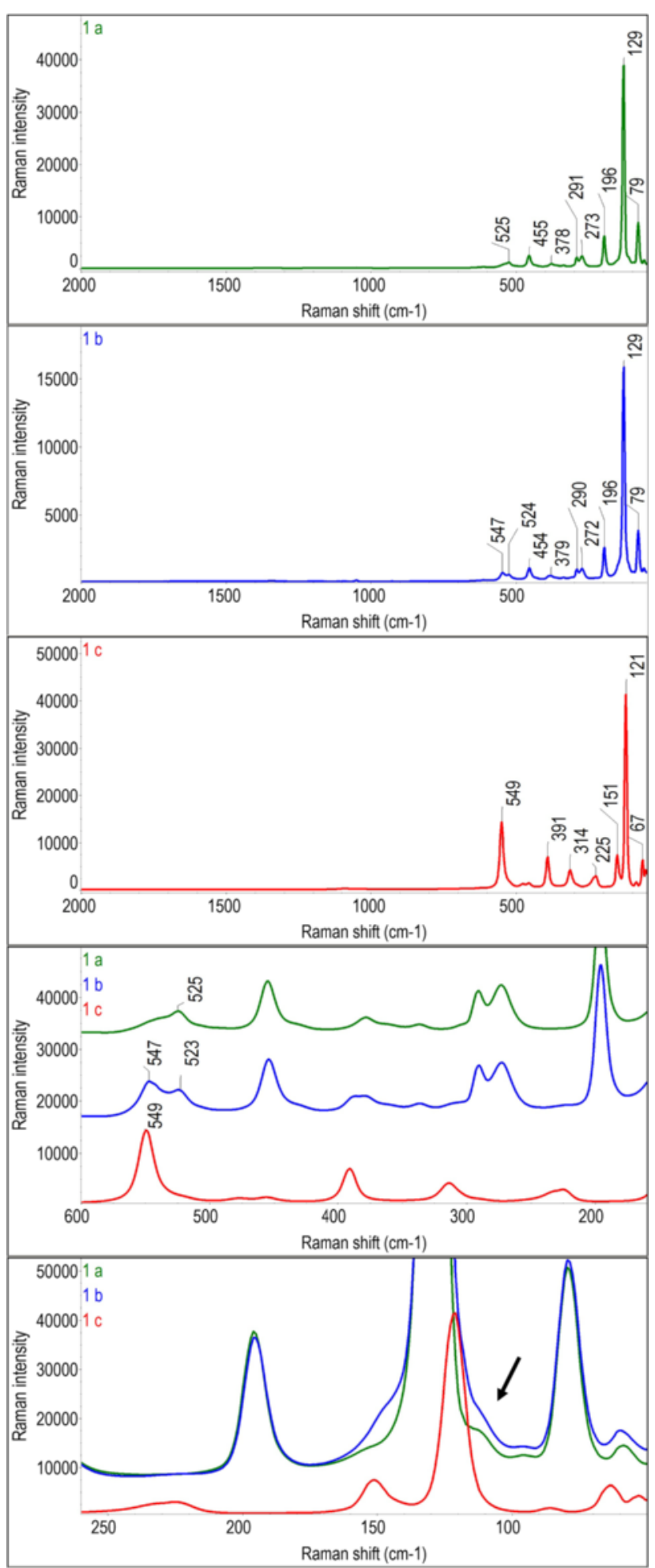

Figure 1 Raman spectra of standard pigment lead tin yellow type I. Raman spectra of lead tin yellow type I and minium in the range of $50-2000 \mathrm{~cm}^{-1}$ with two details of spectra variation observed in the region 50-600 $\mathrm{cm}^{-1}: 1 \mathrm{a}$ ) and 1b) lead tin yellow type I (Böke \& Fritz Art.No.101-7); 1c) minium (Kremer No. 42500). Fourth picture from above: Raman spectra of all pigments in the region of $160-600 \mathrm{~cm}^{-1}$, in the spectrum 2b higher Raman band at $547 \mathrm{~cm}^{-1}$ is visible; last picture: Raman spectra of all pigments in the region of $40-260 \mathrm{~cm}^{-1}$, in the spectrum $2 \mathrm{~b}$ broadening of the Raman band around $131 \mathrm{~cm}-1$ is showed with the arrow. 
Brod Altarpiece (1345-1350), where the lead tin yellow type II was used in green and yellow draperies of the clothing (Figure 3a and b). Pigment was found usually in the green cloak of St. John the Baptist or in the yellow reverse cloaks of Virgin Mary and other saints and was most often mixed with lead white, yellow ochre, earth pigments and green copper pigments.

In the Luxembourg period, especially during the rule of the emperor Charles IV., the royal city of Prague was the cosmopolitan center of art and culture of Central Europe. Consequently, new stimuli were assumed in the field of art and handicrafts. Already in the 40' of the 14th century the Bohemian art reflected the trends of the art of Western Europe (esp. France, Rhineland, Italy) not only in iconography and style, but also in the production technology. The Bohemian panel paintings of the $50^{\prime}$ and $60^{\prime}$ of the 14th century are apparently linked to Italy (initially in particular to Tuscany); that is manifested by the specific formation of the flash and the choice of the decorative techniques. Apart from wandering artists the domestic masters came in contact with Italian art also through imported contemporary artworks.

For this reason the question about the provenance of the lead tin yellow type II in the workshop of the Master of the Vyšší Brod Cycle is very interesting. In Bohemia there is also very significant medieval tradition of glassmaking. The most numerous group of findings from this period is the group of sodium-calcium glasses $\left(\mathrm{Na}_{2} \mathrm{O}-\mathrm{CaO}-\mathrm{SiO}_{2}\right)$. However, a glass containing lead oxide $\mathrm{PbO}$ was found marginally [42]. The painting technique, dating of the artwork and also findings in the literature sources indicate rather the import of the pigment from Italy.

Analogical use of the lead tin yellow type II was discovered also in the workshop of Magister Theodoricus, even though the findings were limited to a small amount of samples, usually taken from green areas of the paintings. The major yellow pigments of this important workshop were yellow ochre and earth pigments [43].

More variable usage of the lead tin yellow type II was documented in the artwork Votive Panel of John Očko from Vlašim and in particular in the workshop of the Master of the Třebon Altarpiece. The yellow pigment was found in the plain areas of green and yellow draperies as well as in the decorative painting brocade of the cloak of St. Jerome (Master of the Třebon altarpiece, Deposition/SS Giles, Augustine, Jerome) and soldier's robe on the panel painting Crucifixion from the church of St. Barbora of the same author. In this ultimate panel painting the yellow was found not only on the important painting brocade but also on the robe of saints and assisting figures and on the fragments of the marbling on the reverse side.
Decorative painting brocade was in major part carried out using the pattern for the application of the lead tin yellow type II on a silver leaf with an admixture of gold (cvishgolde). The green shadows were applied using the copper green pigment on the dark organic glazing (Figure 4a and b).

Samples from the artworks of the Master of the Vyšší Brod altarpiece and the Master of the Třebon Altarpiece that were analyzed by means of Raman spectroscopy contain lead tin yellow type II that shows uniform composition from the chemical point of view (Raman spectra presented in Figures $3 \mathrm{~b}$ and $4 \mathrm{~b}$ ). In the cross-sections and microscopical preparations isotropic glassy like particles with lemon yellow internal reflections, translucent with light yellow colour and very high relief were observed by means of optical microscopy (see Figure 3a). Among the presence of other pigments the lead white was frequently found in the layer with the lead tin yellow type II. There were marginally identified also the admixtures of vermilion, black pigment and ochre. For example, both shadow and light areas of the yellow robe of St. Ludmila on the Votive Panel of John Očko from Vlašim were coloured with the yellow ochre.

The last example of individual employment of the lead tin yellow type II was found on the Triptych with the Death of the Virgin called the Roudnice Altarpiece - inside of right wing, painting of the Man of Sorrows and eight kneeling devotees assigned to the period 1410-1420. Lead tin yellow type II was identified in particular in the painting of the bishop's collar and was located in the lower layer applied on the white layer of lead white (imprimiture) on the ground made of chalk. This lower yellow layer is then covered by a second lighter yellow layer in which the presence of lead tin yellow type I alone was confirmed. This unusual combination of layers will be subjected to an additional investigation (to be published separately).

The earliest use of the lead tin yellow type I was identified on the artwork Votive panel, called from Dubeček which has been assigned already before c. 1390 . This pigment was then confirmed on all the investigated artworks that were dated up to 1550 (Table 2). It was used frequently in yellow draperies, most often in mixture with lead white, as well as in green areas of the paintings where the combination with copper green pigments, usually verdigris with lead white, were mostly confirmed. In rare cases the admixtures of ochre or earth pigments, azurite or black pigment were identified. In the artwork Altarpiece with the Execution of St. Barbara, called the St. Barbara Altarpiece from Osek - St. Sebastian/St. Paul by the Monogrammist IW the lead tin yellow type I was found in the layers of flash, together with lead white, chalk, black pigment, vermilion and red lake.

A special group of artworks are the paintings where the presence of both types of yellows in one layer was 


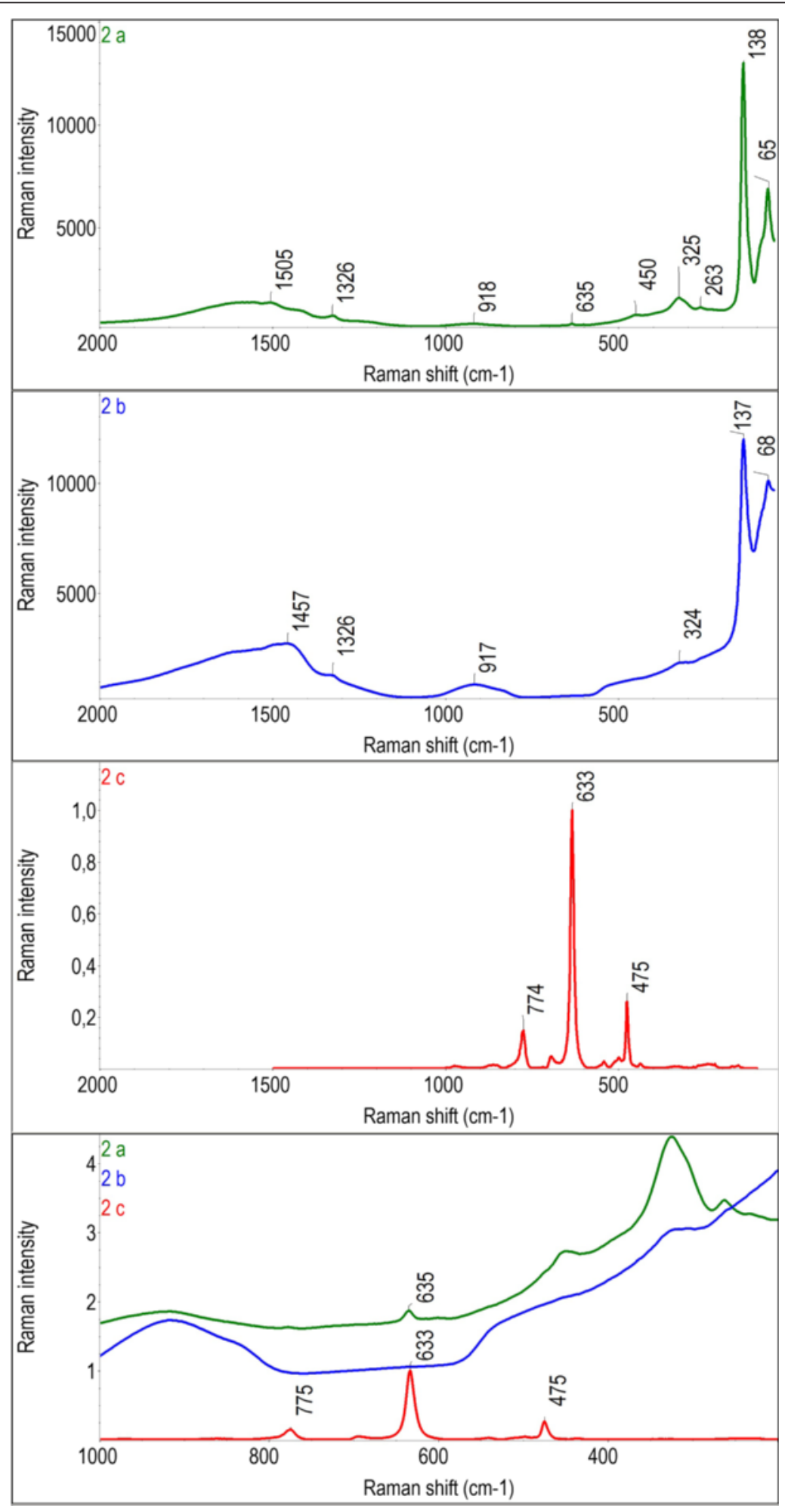

Figure 2 Raman spectra of standard pigment lead tin yellow type II. Raman spectra of lead tin yellow type II and cassiterite $\left(\mathrm{SnO}_{2}\right)$ in the range of 50-2000 $\mathrm{cm}^{-1}$ with one detail of spectra variation observed in the region around $633 \mathrm{~cm}^{-1}: 2 \mathrm{a}$ ) and $2 \mathrm{~b}$ ) lead tin yellow type II (Kremer No. 10120); 2c) mineral cassiterite $\left(\mathrm{SnO}_{2}\right)$. Detail: Raman spectra of all pigments in the region of $200-1000 \mathrm{~cm}^{-1}$, in the spectrum $2 \mathrm{~b}$ Raman band at $635 \mathrm{~cm}^{-1}$ is visible that indicates the presence of mineral cassiterite $\left(\mathrm{SnO}_{2}\right)$. 
confirmed by the Raman spectroscopy. This occurrence was documented on two different artworks and in both cases the pigments were detected by measurement of individual grains in diverse areas. The first artwork is the painting from the Master of the Litomeríice Altarpiece, St. Catherine Altarpiece - St. Catherine before the Emperor Maxentius (Figure 5a and b). The pigments were found in particular in the green cloak of the Emperor where the minor content of lead tin yellow type II was identified in predominant type I. This combination was found for example in the work of Perugino [36]. The contamination of the lead tin yellow type I by silica during the preparation can not be excluded because of the close connection between the preparations of both types of yellows. The second case is the painting from the Master of the Trebon Altarpiece and his workshop, Our Lady Ara Coeli. Here the mixture was detected in the green cloak of St. Margaret and the dominant component was the lead-tin yellow type II with a minor content of type I. Considering that this sample contains also an individual grain of non-uniform composition where both types of yellow as well as minium were found, we presume that what is found are secondary products from an insufficient firing during the production of the pigment. These findings are now under other studies and will be published soon in a separate report.

\section{Conclusions}

Investigation and scientific analysis, especially the combination of optical microscopy and Raman microspectroscopy, showed the frequent use of lead tin yellow type I and II during the High and Late Gothic period in the Bohemian panel paintings. Lead tin yellow type II was confirmed in the artworks assigned to the period from c. 1345 to 1420 . Lead tin yellow type I was confirmed on the paintings from 1390 on. On panel paintings both yellows were used like single pigments or in various pigment mixtures in the colour painting layers. In the yellow areas, the most common combinations were with lead white and earth pigments. Sometimes mixtures with vermilion and red lake were found. In the green areas lead tin yellows were mixed with copper green pigments and lead white. The lead tin yellow type II occurs in this country in the 14th century on better quality artworks where the close links to progressive trends can be assumed. The knowledge of the use of the lead tin yellow type II was a normal part of workshop practice. Various techniques using the lead tin yellow type II were

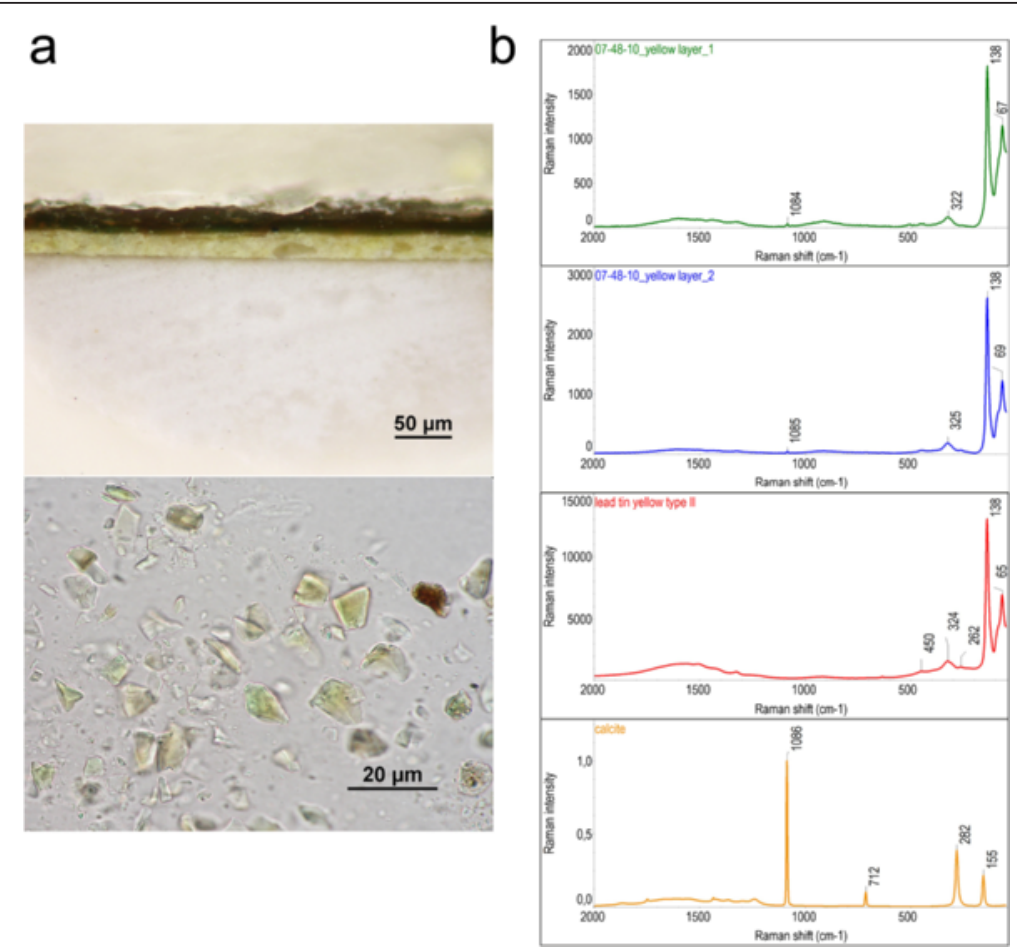

Figure 3 Master of the Vyšší Brod Cycle, Vyšší Brod Cycle - Descent of the Holy Ghost (O 6794). a Cross-section and microscopical preparation of sample taken from the yellow cloak on the left side. The yellow layer of lead tin yellow type II is located on the white ground layer of chalk. Microscopical preparation shows the isotropic glassy like particles with lemon yellow internal reflections, translucent with light yellow colour and very high relief. Photo@2014 National Gallery in Prague. b Raman spectra collected from the yellow layer of the sample. The spectra show the typical Raman bands of lead tin yellow type II: 1) Raman spectrum collected from the sample 07-48-10 no. 1, 2) Raman spectrum collected from the sample 07-48-10 no. 2, 3) Raman spectrum of the standard pigment lead tin yellow type II, 4) Raman spectrum of calcite (chalk). 

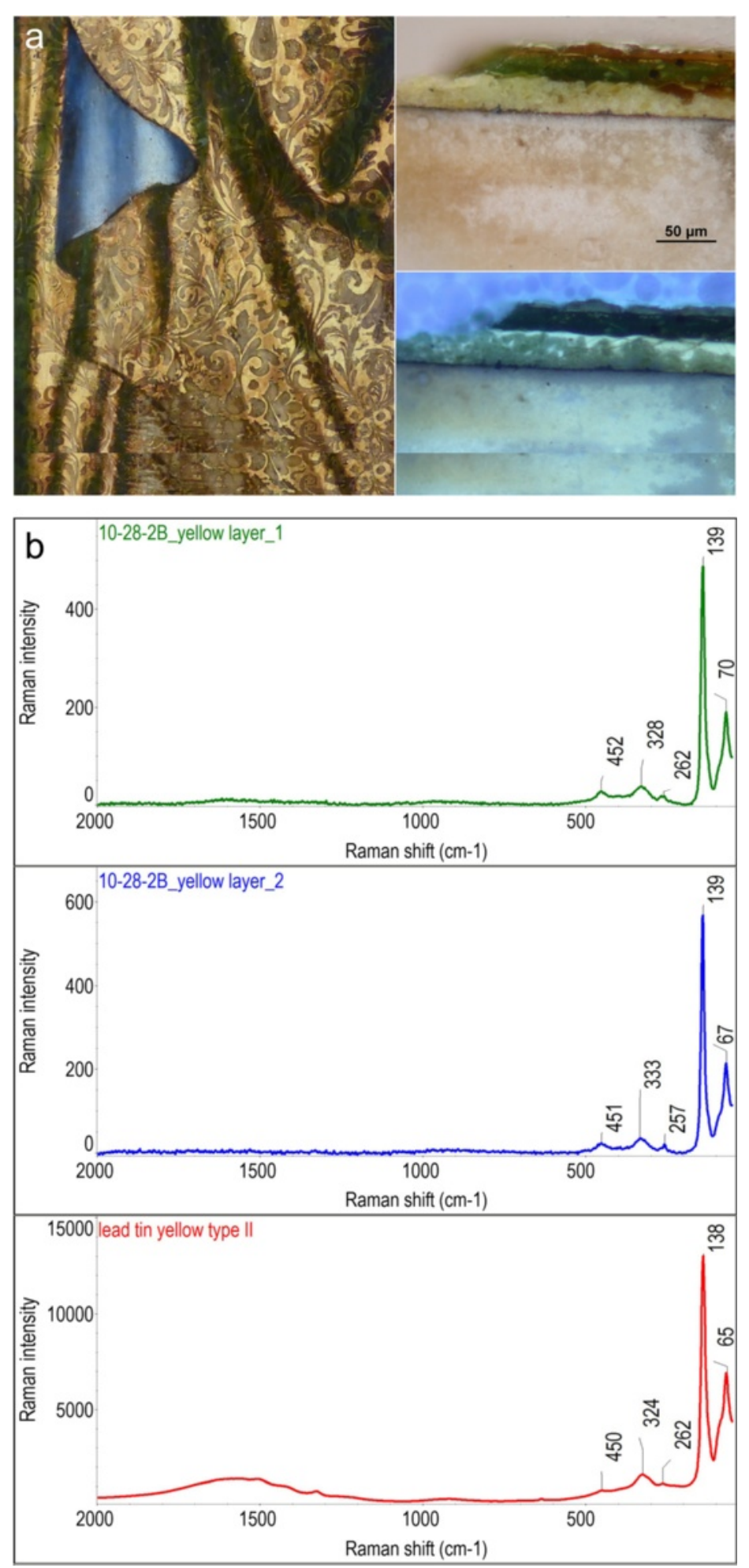

Figure 4 Master of the Třeboň Altarpiece, SS Giles, Augustine, Jerome (O 1266). a Detail and cross-section of the sample taken from decorated yellow robe of St Jerome observed in optical microscope in normal and ultraviolet light. Cross-section shows yellow layer of lead tin yellow type II mixed with lead white on a silver leaf with the admixture of gold (cvishgolde). The final green shadows were realized by applying the copper green pigment on the dark organic layer. Photo@2014 National Gallery in Prague. b Raman spectra collected from the sample of decorated yellow robe of St Jerome, detail in Figure 4a. By means of Raman spectroscopy uniform composition of the pigment lead tin yellow type II was observed: 1) Raman spectrum collected from the yellow layer of the sample $10-28-2 B$ no. 1, 2) Raman spectrum collected from the yellow layer of the sample 10-28-2B no. 2, 3) Raman spectrum of the standard pigment lead tin yellow type II. 
combined in a single workshop (Master of the Třebon Altarpiece) with regard to the requirements of the final aesthetic quality (drapery, decorative painting). It is attractive to assume that the first use of this technique in Bohemia was linked with the arrival of foreign masters, especially those from the area of Italy, working on prestigious orders in connection with the flourishing of the royal court. It is also highly probable that some local masters were acquainted with the use of the lead tin yellow type II as a specific pigment during their travels.

This broader survey brings the first summary of the findings acquired within the framework of the historical art fund of Bohemia. It was initiated in particular with regard to present more general conclusions, in an effort to provide support for the identification of lead tin yellows within the framework of the analyses

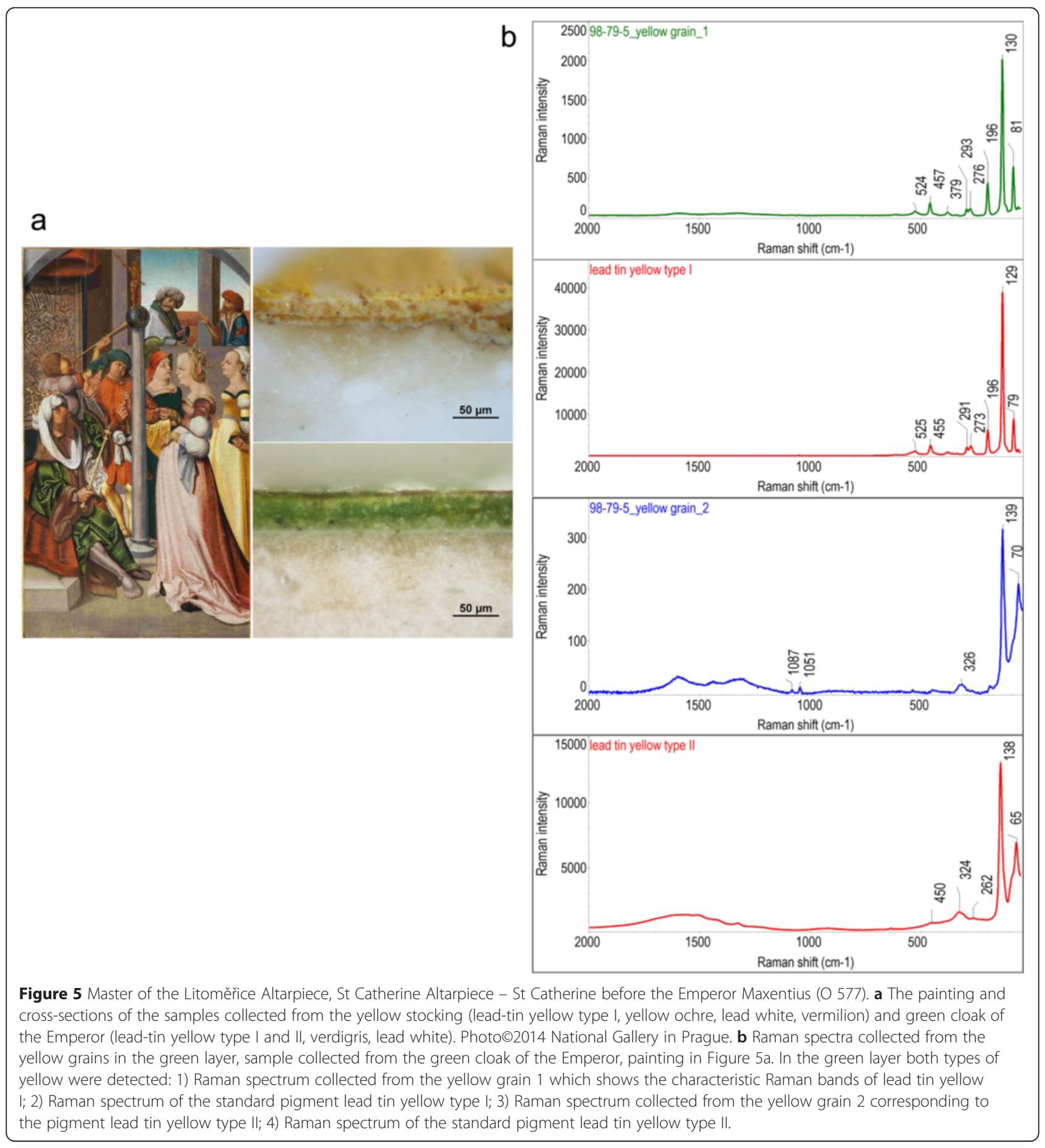


of material research. Raman micro-spectroscopy proved to be a crucial method for identification of both lead tin yellow pigments.

\section{Competing interests}

The authors declare that they have no competing interests.

\section{Authors' contributions}

RŠ as conservation scientist performed the analysis by means of Raman spectroscopy, carried out the laboratory work and significantly contributed to the scientific part of the article. $\breve{C} \mathrm{C}$ as art historian contributed significantly to the historical aspects of the work, both during the project realization as well as by the contribution to the article. $\mathrm{AH}$ as conservation scientist performed the analysis by means of Raman spectroscopy, carried out the laboratory work and significantly contributed to the scientific part of the article. All authors read and approved the final manuscript.

\section{Acknowledgements}

This work was performed within the project: Historical technologies and modern methods of research. The interpretative possibilities of the specialized methods of research of medieval artworks using innovative technologies. of the Ministry of Culture of the Czech Republic.

(Identification code: DF 13P010V010)

\section{Received: 7 October 2014 Accepted: 13 April 2015}

\section{Published online: 11 May 2015}

\section{References}

1. Fajt J. Magister Theodoricus, dvorní malî́ císaře Karla IV. In: Fajt J, editor. Magister Theodoriscus dvorní malî̌ císaře Karla IV. Umělecká výzdoba posvátných prostor hradu Karlštejn. Prague: National Gallery; 1997. p. 281-346.

2. Royt J. Mistr Třeboňského oltáře. Praha: Karolinum; 2013.

3. Sefců R, Chlumská S, Třeštíková A. Materiálový průzkum vybraných děl Mistra litoměřického oltáře a jeho dílny. Technika deskové malby. In: FÓRUM 2012 pro konzervátory-restaurátory. 2012. p. 3-17.

4. Pešina J. Tafelmalerei der Spätgotik und der Renaissance in Böhmen: 1450-1550. Prague: Artia; 1958.

5. Pešina J. Die Tafelmalerei am Jagellonenhof in Prag, 1471-1526. In: Acta historiae artium Academiae Scientiarum Hungaricae, 19. 1973. p. 207-30 20, 1974: 37-80.

6. Fajt J. Karl IV., Kaiser von Gottes Gnaden: Kunst und Repräsentation des Hauses Luxemburg 1310-1437 [Ex. Cat. Prague-New York 2005-2006]. Edited by Fajt J. München; 2006.

7. Kesner L. Mistr IW [Ex. Cat. Litoměřice 1993]. Litoměřice, 1993: 19-21, 39-40.

8. Chamonikola $K$, editor. Lucas Cranach a české země: pod znamením okrídleného hada = Lucas Cranach and the Czech lands: under the sign of the winged serpent, [Ex. Cat. Správa Pražského hradu 2005-2006]. Praha, 2005

9. Chlumská Š, editor. Bohemia \& Central Europe 1200-1550: the permanent exhibition of the collection of Old Masters of the National Gallery in Prague at the Convent of St Agnes of Bohemia. National Gallery: Prague; 2006.

10. Merrifield MP. Original Treatises on the Arts of Painting, vol. II. London: William Cloves and Sons; 1849. Bolognese manuscript, translated and published by Merrifield.

11. Merrifield MP. Original Treatises on the Arts of Painting, vol. II. London: William Cloves and Sons; 1849. Paduan manuscript, translated and published by Merrifield.

12. Manuscript from Montpellier (transcripted 1536), discussed in: Saccaroni C: Giallorino. Storia dei pigmenti gialli di natura sintetica. 2006.

13. Merrifield MP. Original Treatises on the Arts of Painting, vol. I. London: William Cloves and Sons; 1849.

14. Lomazzo GP. Trattato dell'arte della pittura, scoltura ed architettura. Milan: Per Paolo Gottardo Pontio; 1585.

15. Borghini R. I/ riposo. 1584. Discussed in: Saccaroni C: Giallorino. Storia dei pigmenti gialli di natura sintetica. 2006

16. Merrifield MP. Original Treatises on the Arts of Painting, vol. II. London: William Cloves and Sons; 1849.

17. Lomazzo GP. A tracte containing the artes of curious paintinge, caruinge \& building. Translated by Haydock R. Printed at Oxford: loseph Barnes for R.H, 1598.
18. Harley RD. Lead Antimonate Yellow. In: Feller L, editor. Artists' Pigments A Handbook of Their History and Characteristics, Vol. 1. London: Cambridge University Press; 1986. p. 219-54.

19. Kühn H. Lead-Tin Yellow. In: Roy A, editor. Artists Pigments, A Handbook of Their History and Characteristics, vol. 2. Balding + Mansell, Norwich: National Gallery of Art Washington; 1993. p. 83-64.

20. Saccaroni C. Giallorino. Storia dei pigmenti gialli di natura sintetica. 2006

21. Sandalinas C, Ruiz-Moreno S, López-Gil A, Miralles J. Experimental confirmation by Raman spectroscopy of a $\mathrm{Pb}$-Sn-Sb triple oxide yellow pigment in sixteenth-century Italian pottery. J Raman Spectroscopy. 2006;37:1146-53

22. Pelosi C, Santamaria U, Agresti G, Mattei E, De Santis A. Production and characterisation of lead, tin and antimony based yellow pigments. In: Townsend JH, Toniolo L, Cappitelli F, editors. Proceedings of the International Conference Conservation Science 2007, Milan 10-11 May, 2007. London: Archetype Publication; 2008. p. 187-8.

23. Clark RJH, Cridland L, Kariuki BM, Harris KDM, Withnall R. Synthesis, structural characterisation and Raman spectroscopy of the inorganic pigments lead tin yellow types I and II and lead antimonate yellow: their identification on medieval paintings and manuscripts. J Chem Soc Dalton Trans. 1995:16:2577-82

24. Jacobi R. Über den in der Malerei verwendeten gelben Farbstoff der alten Meister. Angewandte Chemie. 1941;54:28-9.

25. Eastaugh N, Walsh V, Chaplin T, Siddall R. Pigment Compendium: A Dictionary and Optical Microscopy of Historical Pigments. Oxford: Butterworth-Heinemann; 2008. p. 237-9.

26. Duran A, Siguenza MB, Franquelo ML, Jimenez de Haro MC, Justo A, Perez-Rodriguez JL. Murillo's paintings revealed by spectroscopic techniques and dedicated laboratory-made micro X-ray diffraction. Anal Chim Acta. 2010:671(1-2):P1-8.

27. Deneckere A, Hocquet FP, Born A, Klein P, Rakkaa S, Lycke S, et al. Direct analysis of the central panel of the so-called Wyts triptych after Jan van Eyck. J Raman Spectroscopy. 2010;41:1500-9.

28. Bagdzevičiene J, Tautkus S. St Bruno, A Miracle in the Church: Investigation of the Painting Technique. Chemija. 2011;22:33-40.

29. Ferrero LL, Roldán C, Ardid M, Navarro E. X-ray fluorescence analysis of yellow pigments in altarpieces by Valencian artists of the XV and XVI centuries. Nucl Instrum Methods Phys Res. 1999;422:868-73.

30. Edwards HGM. Analytical Raman spectroscopic discrimination between yellow pigments of the Renaissance. Spectrochim Acta A Mol Biomol Spectrosc. 2010;80:14-20.

31. Kühn H. Lead-tin yellow. Stud Conservation. 1968;13:7-33.

32. Martin E, Duval AR. Les deux varietes de jaune de plomb et d'etain: etude chronologique. Stud Conservation. 1990;35:117-36.

33. Kühn H. Lead-Tin Yellow. Artists Pigments, A Handbook of Their History and Characteristics: Vol. 2. Roy A, editor. National Gallery of Art Washington; 1993:101-10.

34. Penny N, Spring M. Veronese's paintings in the National Gallery, Technique and Materials: Part I. Natl Gallery Tech Bull. 1995;16:4-29.

35. Aloupi H, Aslani I, Pachalis V, Stassinopoulos S, Karydas A, Anglos D, Gionis V, Chryssikos J: Analysis and documentation of the Baptism by Domenicos Theotokopoulos by use of non-destructive physicochemical techniques. Comparison with the Adoration of the Magi of the Benaki Museum. International Meeting of the Special Interest Icons Group Icons Approaches to Research, Conservation and Ethical Issues. Athens, 3-7 December 2006.

36. Borgia I, Brunetti BG, Miliani C, Ricci C, Seccaroni C, Sgamellotti A. The combined use of lead tin yellow type I and II on a canvas painting by Pietro Perugino. J Cultural Heritage. 2007:8:65-8.

37. Trojek T, Musíle L, Čechák T. X-ray fluorescence analysis of cultural artefacts-Applications to the Czech heritage. Radiat Physics Chem. 2014;95:381-4

38. Egerton RF. Physical Principles of Electron Microscopy. New York: Springer US; 2007.

39. Ferraro JR, Nakamoto K, Brown CW. Introductory Raman Spectroscopy. San Diego: Academic Press; 2003.

40. Eastaugh N, Walsh V, Chaplin T, Siddall R. Pigment Compendium. A Dictionary and Optical Microscopy of Historical Pigments. 2008. p. 706-9.

41. Vigouroux JP, Husson E, Calvarin G, Dao NQ. Vibrational spectroscopic study of the oxides $\mathrm{Pb}_{3} \mathrm{O}_{4} \mathrm{SnPb}_{2} \mathrm{O}_{4}$ and $\mathrm{SnPb}\left(\mathrm{Pb}_{2} \mathrm{O}_{4}\right)_{2}$. Spectrochimica Acta. 1982;38A(4):393-8. 
42. Drahotová O, editor. Historie sklárské výroby v českých zemích. Praha: Academia; 2005

43. Blochová H. Výtvarné technologie a výzdoba kaple Sv. Kríiže. In: Fajt J, editor. Magister Theodoriscus dvorní malî́ císaře Karla IV. Umělecká výzdoba posvátných prostor hradu Karlštejn. Prague: National gallery; 1997. p. 600-10.

\section{Publish with ChemistryCentral and every} scientist can read your work free of charge

"Open access provides opportunities to our colleagues in other parts of the globe, by allowing anyone to view the content free of charge."

W. Jeffery Hurst, The Hershey Company.

- available free of charge to the entire scientific community

- peer reviewed and published immediately upon acceptance

- cited in PubMed and archived on PubMed Central

- yours - you keep the copyright

Submit your manuscript here:

Submit your manuscript here:
http://www.chemistrycentral.com/manuscript/<smiles>c1ccccc1</smiles> 